\title{
Attitudes, beliefs and barriers for adherence to the hyposodic diet in patients with heart failure
}

\author{
Atitudes, crenças e barreiras para a adesão à dieta hipossódica \\ em pacientes com insuficiência cardíaca \\ Actitudes, creencias y barreras para la adhesión a la dieta \\ hiposódica en pacientes con insuficiencia cardíaca

\section{Simone Maria Muniz da Silva Bezerra ${ }^{a}$ Bianka Santos Lopes ${ }^{b}$ Patrícia Ponciano Bomfim ${ }^{b}$ Rebeka Maria de Oliveira Belo ${ }^{a}$ Monique Oliveira do Nascimento ${ }^{a}$ Hirla Vanessa Soares de Araújo ${ }^{a}$ Alyson Samuel de Araujo Bragab}

\section{How to cite this article:} Bezerra SMMS, Lopes BS, Bomfim PP, Belo RMO, Nascimento MO, Araújo HVS, Braga ASA. Attitudes, beliefs and barriers for adherence to the hyposodic diet in patients with heart failure. Rev Gaúcha Enferm. 2020:41:e20190304. doi: https://doi.org/10.1590/19831447.2020.20190304
${ }^{a}$ Universidade de Pernambuco (UPE). Faculdade de Enfermagem Nossa Senhora das Graças. Programa Associado de Pós-Graduação em Enfermagem UPE/ UEPB. Recife, Pernambuco, Brasil.

- Universidade de Pernambuco (UPE). Faculdade de Enfermagem Nossa Senhora das Graças. Recife, Pernambuco, Brasil.

\section{ABSTRACT}

Objectives: To identify attitudes, beliefs and barriers to adherence to the hyposodic diet in patients with heart failure and associated factors. Methods: Cross-sectional study with 41 individuals. The Dietary Sodium Restriction Questionnaire was used. Fisher's test was applied for analysis. Results: Attitudes were based on family and professional relationships; in the beliefs, it was highlighted to believe in the diet to improve health. As barriers, insufficient efforts were found to change the diet and taste of low salt foods. It was associated with adherence among the components factors such as: income, perception of cardiac improvement with the diet, family history of renal and heart failure and family adherence to the diet

Conclusions: The identified attitudes and beliefs refer, respectively, to social relationships and trust in the diet to improve health status. The barriers were: insufficient effort to modify the diet and food palatability. Economic, family and clinical factors were associated with hyposodic adherence.

Keywords: Nursing. Heart failure. Diet, sodium-restricted

\section{RESUMO}

Objetivos: Identificar atitudes, crenças e barreiras para a adesão à dieta hipossódica em pacientes com Insuficiência Cardíaca e fatores associados.

Métodos: Estudo transversal com 41 indivíduos. Utilizou-se o Questionário de Restrição de Sódio na Dieta. Para análise aplicou-se o teste de Fisher.

Resultados: As atitudes basearam-se nas relações familiares e com profissionais; nas crenças destacou-se acreditar na dieta para melhoria da saúde. Como barreiras, encontrou-se empenho insuficiente para mudança dietética e sabor dos alimentos com pouco sal. Associou-se à adesão entre os componentes fatores como: renda, percepção da melhora cardíaca com a dieta, histórico familiar de insuficiência renal e cardíaca e adesão familiar à dieta.

Conclusões: As atitudes e crenças identificadas referem-se, respectivamente, às relações sociais e à confiança na dieta para melhorar a condição de saúde. As barreiras foram: empenho insuficiente em modificar a dieta e a palatabilidade alimentar. Fatores econômicos, familiares e clínicos estiveram associados à adesão hipossódica.

Palavras-chave: Enfermagem. Insuficiência cardíaca. Dieta hipossódica.

\section{RESUMEN}

Objetivos: Identificar actitudes, creencias y barreras para la adhesión a la dieta de hiposodio en pacientes con insuficiencia cardíaca y factores asociados.

Métodos: Estudio transversal con 41 individuos. Se utilizó el Cuestionario de restricción de sodio en la dieta. La prueba de Fisher se aplicó para el análisis.

Resultados: Las actitudes se basaron en las relaciones familiares y profesionales; En las creencias, se destacó creer en la dieta para mejorar la salud. Como barreras, se encontraron esfuerzos insuficientes para cambiar la dieta y el sabor de los alimentos bajos en sal. Se asoció con la adherencia entre los factores componentes como: ingresos, percepción de mejoría cardíaca con la dieta, antecedentes familiares de insuficiencia renal y cardíaca y adherencia familiar a la dieta.

Conclusiones: Las actitudes y creencias identificadas se refieren, respectivamente, a las relaciones sociales y la confianza en la dieta para mejorar el estado de salud. Las barreras fueron: esfuerzo insuficiente para modificar la dieta y la palatabilidad de los alimentos. Factores económicos, familiares y clínicos se asociaron con baja adherencia al sodio.

Palabras clave: Enfermería. Insuficiencia cardíaca. Dieta hiposódica. 


\section{INTRODUCTION}

Non-pharmacological measures are an integral part of treatment for Cardiovascular Diseases (CVD), especially in Heart Failure (HF), which is considered a common outcome in most diseases that affect the cardiovascular system. HF is defined as the inability of the heart to supply enough blood to the body, so that it does not meet all tissual needs for oxygen and nutrients in the organism(1).

The prevalence of HF reaches around 23 million people worldwide and in the national territory, the disease is one of the main causes of hospitalization, especially in clinically decompensated individuals ${ }^{(1-3)}$. When considering these aspects, it is undeniable to recognize that decompensated HF causes direct damage to human lives, in addition to requiring large public spending on treatment and hospitalizations.

Dietary sodium restriction is the most recommended non-pharmacological measure for patients with $\mathrm{HF}$ and non-adherence to this measure is one of the causes of clinical decompensation ${ }^{(4-6)}$. In addition, the decrease in sodium consumption has been encouraged as a strategy to combat Chronic Noncommunicable Diseases (CNDs) in Brazil and worldwide ${ }^{(7-8)}$.

Despite orientations of health professionals regarding the moderation of sodium in the diet, this measure does not have high adherence, since there are factors that collaborate and others that difficult or prevent individuals from adhering to the hyposodic diet. Such factors are called facilitators and barriers, respectively ${ }^{(5-6)}$.

The Dietary Sodium Restriction Questionnaire (DSRQ) has been used to identify some of these factors. The instrument is based on the Theory of Planned Behavior (TPB), which supports the idea of human behavior being guided by beliefs that condition in individuals favorable or unfavorable attitudes for their self-care. According to TPB, attitudes, subjective norms and perceived behavioral control are the three main constructs underlying behavior change $\mathrm{e}^{(9-11)}$.

Some studies that used the DSRQ pointed out as factors that interfere in adherence to dietary sodium restriction: the opinion of family members and health professionals, palatability and food preferences, gender, functional class of HF, income, ethnicity, comorbidities, smoking and deficit in self-care ${ }^{(6,9,12)}$.

Nursing has gained great prominence in the treatment and rehabilitation of these patients with $\mathrm{HF}$, since the nurse has the handling of non-pharmacological interventions. Within this context, nursing plays an important role in monitoring, promoting, health education and treating patients with $\mathrm{HF}^{(13-14)}$.
However, in view of the fact that many health professionals have still found it difficult to accurately measure the causes of clients'non-engagement with changes in behavior for the acceptance of non-pharmacological treatment of $H F$, especially a low sodium menu, it is noted, therefore, the need to develop researches that contributes to address some of these existing gaps that challenge the multidisciplinary team and the health system ${ }^{(1)}$.

Therefore, when considering the magnitude of HF and its clinical repercussions related to inadequate sodium consumption in the diet, identify the attitudes, beliefs and barriers to adherence to a low sodium diet, as well as the associated factors, in a population of patients affected by HF, become essential and it constitute the objective of this study.

\section{$\square$ METHODS}

Quantitative, cross-sectional study, carried out in the Myocardial Infirmary of the Pronto Socorro Cardiológico de Pernambuco Professor Luiz Tavares - PROCAPE, teaching hospital belonging to the Universidade de Pernambuco (UPE).

The patients sample was calculated using the Epiinfo ${ }^{\text {TM }}$ Version 7.2 software based on an average population of 20 patients, admitted to the ward per month, and a $50 \%$ prevalence of HF. When considering a 95\% confidence interval and a sampling error of 5\%, it got a sample of 19 individuals. However, in order to increase the internal validity of the study, it was decided to include 41 patients.

The sampling process was carried out for convenience, and patients present in the sector were recruited during the data collection period (August to December 2017) and were available for the interview. The nurse's sense was consulted to check the patients who met the inclusion criteria and then the patients were invited to participate in the study.

The inclusion criteria for the research were defined as: adult individuals and diagnosed with HF. Patients with clinical instability were excluded, and this condition was considered when the patient was using vasoactive drugs, on continuous oxygen inhalation therapy or with respiratory distress.

For data collection, two instruments were used: a sociodemographic and clinical questionnaire, developed by the researchers with objective answers and the second, constitutes the DSRQ, which based on TPB, assesses the attitudes, beliefs and barriers to adherence to the diet with low sodium content in individuals with $\mathrm{HF}^{(6)}$. This has been validated for use in Brazi|(10-11).

The variables of the first collection instrument were: age, gender, marital status, place of birth, education, occupation, income, time of diagnosis, number of hospitalizations, main complaint of the current hospitalization, personal and family 
history of comorbidities, patient knowledge about illness, information received on HF by health professionals, follow-up of low-sodium diet by family members, habit of eating out and using industrialized foods.

With regard to the DSRQ, the instrument consists of 27 items in total, subdivided into two sections. Section 1 provides information on the follow-up of the hyposodic diet, the difficulty degree of follow-up and the patient's perception of the effect of the diet on the control of the cardiac condition. Section 2 allows the assessment of individuals' beliefs and barriers to adherence to the sodium-restricted diet and contains a five-point Likert scale for each question. This section is subdivided into three subscales ${ }^{(10)}$ :

Subscale 1 - Component Attitude and Subjective Norm: this subscale allows the patient to be evaluated in relation to their beliefs about the positive results of the diet in their health condition, as well as the importance of other people to approve or not the sodium restriction in the diet. Scores range from 9 to 45 points.

Subscale 2 - Perceived Behavioral Control: this subscale allows assessing the patient's capacity to perceive the aspects of his daily life that act as facilitators or barriers in adhering to a hyposodic diet. Scores range from 4 to 20 points.

Subscale 3 - Dependent Behavior: this subscale allows the assessment of factors that contribute to or dificult dietetic restrictions related to the purchase and consumption of food in commercial establishments. Scores range from 3 to 15 points.

For the first subscale analysis, scores 1 and 2 on the Likert scale correspond to the category "Totally disagree", score 3 to the category "neutral", and scores 4 and 5 to the category "Totally agree". For the analysis of the second and third subscales, scores 1 and 2 corresponded to the category "Not at all", scores 3 to "partially (little)" and scores 4 and 5 were assigned to the category "A lot". The cutoff points used for satisfactory adherence are $\geq 40$ points for the Attitude and Subjective Norm subscale; $\leq 8$ for Perceived Behavioral Control; and $\leq 3$ for Dependent Behavior ${ }^{(15)}$.

The data were entered into the SPSS software version 20.0. Categorical variables are presented using absolute and relative frequency. Continuous variables were expressed as measures of central tendency. Fisher's test was used to establish an association between categorical variables, which were dichotomized. It was considered a significance level of 5\%.

In statistical analysis by cross-reference table, the sociodemographic and clinical variables are evaluated, as well as the variables in section I of the DSRQ, according to the classification of adherence between the three subscales. For this evaluation, the variables were dichotomized: age, per capita income, diagnosis time, number of hospitalizations since diagnosis. As for the variables in section I of the instrument, the frequency of following the diet was assessed in terms of whether or not the diet was followed (yes and no), level of difficulty in following the diet (easy and hard) and perception of improvement in cardiac condition (yes and no).

The study was assessed by the Research Ethics Committee under the ethical observances of Resolution No. 466/2012 of the National Health Council and the Resolution 510 of April 7, 2016, obtaining the approval statement under No.: 2,247,127 and CAAE: 71107517.4.0000.5192.

\section{$\square$ RESULTS}

From the 41 (100\%) participants, the average age was 60.8 years $( \pm 14.8)$, with a predominance of male gender (61\%), low education (73.2\%), of individuals with work activity $(92,7 \%)$ and the majority had a per capita income of 1 minimum wage.

Arterial hypertension and diabetes mellitus were among the most mentioned comorbidities, with a relative frequency of $80.5 \%$ and $41.5 \%$, respectively.

The sociodemographic and clinical characterization of the sample are shown in table 1.

According to Section I of DSRQ, 37 (90.2\%) patients had been prescribed a low-salt diet by a health professional. Table 2 shows, among these patients, the frequencies of compliance with the diet, the difficulty level and the perception of heart condition control related to the diet.

Table 3 shows the results obtained in relation to Attitude and subjective Norm, Perceived Behavioral Control and Dependent Behavior, through Section II of the DSRQ.

When the values of central tendency of the scores obtained by each subscale were evaluated, it was observed that in the component attitude and subjective norm, an average score of 40.3 points $( \pm 5.7$ ) was obtained and that $31.7 \%$ of the interviewees obtained the maximum score, which indicates a high adherence to dietary sodium restriction related to beliefs about the favorable effects of diet on health status.

For the perceived behavioral control, the average score obtained was 11.3 ( \pm 2.9 ), pointing out an unsatisfactory adherence to the hyposodic diet in the behavioral aspect. The last subscale brought an average score between individuals of 6.8 ( \pm 4.3$)$ points, suggesting an unsatisfactory adherence from the perspective of dependent behavior.

With regard to the distribution of the frequency of adherence between the three subscales, an unsatisfactory adherence was found predominant for the perceived behavioral control and the dependent behavior (table 4).

The associations found with statistical significance for the factors associated with adherence between the DSRQ section II subscales are shown in table 5 . 
Table 1 - Sociodemographic, clinical and dietary characteristics of patients with heart failure $(n=41)$. Recife, Pernambuco, Brazil, 2017

$\begin{array}{ll}\text { Variables } & N=41\end{array}$

Sociodemographic

Gender (\%)

$\operatorname{Age}^{*}$

Marital status (\%)

Place of birth (\%)

Schooling (\%)

Occupation (\%)

Income (Reais) per capita !
Female

Male

With partner

Without partner

Recife and metropolitan region

Countryside and other states

$\leq 9$ years of study

$>9$ years of study

Yes

No

$468.50(312.33-937.00)$
$16(39)$

$25(61)$

$60.8 \pm 14.8$

$21(51.2)$

$20(48.8)$

$23(56.1)$

$18(43.9)$

$30(73.2)$

$11(26.8)$

$38(92.7)$

$3(7.3)$

$24(4.75-69.00)$

$3.27 \pm 2.46$

Dyspnea and/or Edema

$36(87.8)$

Others/don't know

$5(12.2)$

Yes

$33(80.5)$

No

8 (19.5)

Diabetes Mellitus (\%)

Yes

$17(41.5)$

No

$24(58.5)$

CRI

Yes

$6(14.6)$

No

$35(85.4)$

Family history of HF (\%)

Yes

15 (36.6)

No

$26(63.4)$

Family history of CRI (\%)
$7(17.1)$

$34(82.9)$

No 
Table 1 - Cont.

\begin{tabular}{lll} 
Variables & & $\mathbf{N}=\mathbf{4 1}$ \\
Knowledge about HF (\%) & Yes & $10(24.4)$ \\
Information about HF by health professionals (\%) & Yes & $31(75.6)$ \\
& No & $11(26.8)$ \\
Diet & & $30(73.2)$ \\
Family members adhering to hyposodic diet (\%) & Yes & \\
& No & $19(46.3)$ \\
Habit of eating out & Lives alone & $18(43.9)$ \\
& Yes & $4(9.8)$ \\
Consumption of processed food & No & $19(43.3)$ \\
& Yes & $22(53.7)$ \\
& No & $19(43.3)$ \\
\hline
\end{tabular}

Source: research data, 2017.

Notes: CRl: Chronic Renal Insufficiency; HF: Heart failure. * Continuous variables expressed as averages \pm standard deviation; $\downarrow$ Asymmetric variables presented as median and percentiles $25-75$.

Table 2 - Section I of DSRQ: follow-up frequency of the hyposodic diet, difficulty level and perception of diet-related heart condition control among patients with prescription of sodium-restricted diet $(n=37)$. Recife, Pernambuco, Brazil, 2017

\section{Variables}

\section{N (\%)}

\section{$37(90.2)$}

Never

$7(17)$

Follow-up frequency

Sometimes

$4(9.8)$

Most of the time

$10(24.4)$

Always

$16(39)$

Very hard

$12(29.3)$

Difficulty level

Hard

8 (19.5)

Easy

12 (29.3)

Very easy

$5(12.1)$

No/not at all

$6(14.6)$

Heart condition control

Few

2 (4.9)

A lot

$29(70.7)$

Source: research data, 2017. 
Bezerra SMMS, Lopes BS, Bomfim PP, Belo RMO, Nascimento MO, Araújo HVS, Braga ASA

Table 3 - Frequency of responses to DSRQ Section II subscales ( $n=41)$. Recife, Pernambuco, Brazil, 2017

\begin{tabular}{|c|c|c|c|}
\hline Subscale of Attitude and Subjective Norm & $\begin{array}{c}\text { Totally } \\
\text { Disagree } \\
\text { N (\%) }\end{array}$ & $\begin{array}{l}\text { Neutral } \\
\text { N }(\%)\end{array}$ & $\begin{array}{c}\text { Totally } \\
\text { Agree } \\
\text { N }(\%)\end{array}$ \\
\hline 12. It is important for me to follow a low salt diet. & $1(2.4)$ & $1(2.4)$ & $39(95.1)$ \\
\hline 13. Do a low salt diet will prevent fluid from accumulating in my body. & $0(0)$ & $3(7.3)$ & $38(92.7)$ \\
\hline 14. Following a low salt diet keeps me from getting bloated & $2(4.9)$ & $1(2.4)$ & $38(92.7)$ \\
\hline 15. Do a low salt diet will help me to breathe easier. & $5(12.2)$ & $3(7.3)$ & $33(80.5)$ \\
\hline 16. When I follow a low salt diet, I feel better. & $4(9.8)$ & $2(4.9)$ & $35(85.4)$ \\
\hline 17. Following a low salt diet will keep my heart healthy. & $1(2.4)$ & $1(2.4)$ & $39(95.1)$ \\
\hline $\begin{array}{l}\text { 18. My partner and other family members think that I should follow a } \\
\text { low salt diet. }\end{array}$ & $5(12.2)$ & $1(2.4)$ & $35(85.4)$ \\
\hline 19. I usually want to do what my doctor thinks I should do. & $3(7.3)$ & $10(24.4)$ & $28(68.3)$ \\
\hline $\begin{array}{l}\text { 20. I usually want to do what my partner or family members think I } \\
\text { should do. }\end{array}$ & $9(22)$ & $13(31.7)$ & $19(46.3)$ \\
\hline \multicolumn{4}{|l|}{ Perceived Behavioral Control Subscale } \\
\hline & Not at all & Partially & A lot \\
\hline $\begin{array}{l}\text { 21. I don't understand (the importance of salt control) /I don't know } \\
\text { how to control the amount of salt (eat in restaurants) }\end{array}$ & $32(78)$ & $3(7.3)$ & $6(14.6)$ \\
\hline 22. I like low salt foods & $16(39)$ & $9(22)$ & $16(39)$ \\
\hline 23. What I like to eat is low in salt & $15(36.6)$ & $4(9.8)$ & $22(53.7)$ \\
\hline 24. I don't have the willpower to change my diet & $15(36.6)$ & $2(4.9)$ & $24(58.5)$ \\
\hline \multicolumn{4}{|l|}{ Dependent Behavior Subscale } \\
\hline & Not at all & Partially & A lot \\
\hline 25. I can't choose low-salt food in restaurants & $27(65.9)$ & $2(4.9)$ & $12(29.3)$ \\
\hline 26. The restaurants I like don't serve low salt food & $27(65.9)$ & $2(4.9)$ & $12(29.3)$ \\
\hline 27. I can't choose low salt foods at the supermarket & $25(61)$ & $4(9.8)$ & $12(29.3)$ \\
\hline
\end{tabular}

Source: research data, 2017.

Table 4 - Classification of adherence distributed among DSRQ section II subscales, according pre-established cutoff point ( $n=41)$. Recife, Pernambuco, Brazil, 2017

\begin{tabular}{lccc} 
& $\begin{array}{c}\text { Subjective Attitude } \\
\text { and Norm } \\
\text { N (\%) }\end{array}$ & $\begin{array}{c}\text { Behavioral Control } \\
\mathbf{N}(\%)\end{array}$ & $\begin{array}{c}\text { Dependent Behavior } \\
\text { N (\%) }\end{array}$ \\
\hline Satisfactory Adherence & $28(68.3)$ & $10(24.4)$ & $18(43.9)$ \\
Unsatisfactory Adherence & $13(31.7)$ & $31(75.6)$ & $23(56.1)$ \\
Total & $41(100)$ & $41(100)$ & $41(100)$ \\
\hline
\end{tabular}

Source: research data, 2017. 
Table 5 - Analysis of factors associated with satisfactory adherence between the subscales of section II of the DSRQ ( $n=41)$. Recife, Pernambuco, Brazil, 2017

\begin{tabular}{|c|c|c|c|c|c|c|c|c|c|c|}
\hline \multirow{2}{*}{\multicolumn{2}{|c|}{ Variables }} & \multicolumn{2}{|c|}{$\begin{array}{c}\text { Satisfactory } \\
\text { Adherence - } \\
\text { Subjective } \\
\text { Attitude and } \\
\text { Norm }\end{array}$} & \multirow[t]{2}{*}{$\mathbf{p}^{*}$} & \multicolumn{2}{|c|}{$\begin{array}{c}\text { Satisfactory } \\
\text { Adherence - } \\
\text { Behavioral } \\
\text { Control }\end{array}$} & \multirow[t]{2}{*}{ p* } & \multicolumn{2}{|c|}{$\begin{array}{l}\text { Satisfactory } \\
\text { Adherence - } \\
\text { Dependent } \\
\text { Behavior }\end{array}$} & \multirow[t]{2}{*}{$\mathbf{p}^{*}$} \\
\hline & & Yes & No & & Yes & No & & Yes & No & \\
\hline \multirow{2}{*}{$\begin{array}{l}\text { Per Capita } \\
\text { Income }\end{array}$} & $\leq 1 \mathrm{MW}$ & 27 & 9 & \multirow{2}{*}{0.028} & 9 & 27 & \multirow{2}{*}{1.000} & 16 & 20 & \multirow{2}{*}{1.000} \\
\hline & $>1 \mathrm{MW}$ & 1 & 4 & & 1 & 4 & & 2 & 3 & \\
\hline \multirow{2}{*}{$\begin{array}{l}\text { Family history } \\
\text { of HF }\end{array}$} & Yes & 11 & 4 & \multirow{2}{*}{0.734} & 5 & 10 & \multirow{2}{*}{0.453} & 10 & 5 & \multirow{2}{*}{0.049} \\
\hline & No & 17 & 9 & & 5 & 21 & & 8 & 18 & \\
\hline \multirow{2}{*}{$\begin{array}{l}\text { Family history } \\
\text { of CRI }\end{array}$} & Yes & 4 & 3 & \multirow{2}{*}{0.659} & 4 & 3 & \multirow{2}{*}{0.047} & 2 & 5 & \multirow{2}{*}{0.438} \\
\hline & No & 24 & 10 & & 6 & 28 & & 16 & 18 & \\
\hline \multirow{2}{*}{$\begin{array}{l}\text { Family } \\
\text { members with } \\
\text { salt restrictions }\end{array}$} & Yes & 15 & 4 & \multirow[b]{2}{*}{0.476} & 6 & 13 & \multirow[b]{2}{*}{0.447} & 12 & 7 & \multirow[b]{2}{*}{0.049} \\
\hline & No & 12 & 6 & & 3 & 15 & & 5 & 13 & \\
\hline \multirow{2}{*}{$\begin{array}{l}\text { Cardiac } \\
\text { condition } \\
\text { control }\end{array}$} & Yes & 26 & 5 & \multirow[b]{2}{*}{0.003} & 8 & 23 & \multirow[b]{2}{*}{0.653} & 15 & 16 & \multirow[b]{2}{*}{0.667} \\
\hline & No & 1 & 5 & & 2 & 4 & & 2 & 4 & \\
\hline
\end{tabular}

Source: research data, 2017. Notes: MW: Minimum Wage; HF: Heart Failure; CRI: Chronic Renal Insufficiency. *Fisher's test

\section{DISCUSSIONS}

To this date, this is one of the few studies that used the Brazilian version of the DSRQ in order to identify attitudes, beliefs and barriers to adhering to a hyposodic diet among individuals with $\mathrm{HF}$, since its translation and validation in the Brazilian population ${ }^{(6,10,12)}$. This research was also able to evaluate the factors associated with adherence to the components of attitude and subjective norm, perceived behavioral control and dependent behavior, considering the recent cutoff points validation for adherence to a hyposodic diet in Brazilian patients with $\mathrm{HF}^{(15)}$.

It was predominant among the participants, the receivement prescriptions for a low salt diet. However, this contrasts with the fact that the majority also reported never having received any information about the disease. This finding indicates that although there is a prescription, the benefits of a hyposodic diet may not be embedded in a consolidated manner in professional health practice.
Even though a significant percentage (70.7\%) of patients, with a prescription for hyposodic diet, recognized that following the same help in controlling their heart condition, the difficulty reported by $48.8 \%$ in following it, is probably the reason why only $39 \%$ mentioned always following the dietary sodium restriction. The lack of diet prescription may be a factor that contributes to this difficulty of follow-up, because according to a study that used the Brazilian version of the DSRQ, it was found that among individuals without a prescription for a hyposodic diet, there was greater difficulty reported to be followed ${ }^{(6)}$.

Although the majority of the sample stated that they did not understand what heart failure is, most of the participants have common knowledge about the importance of restricting salt in their diet. This is evidenced in the significant percentage of concordance with the statement "It is important for me to follow a low salt diet" of the Attitude and Subjective Norm subscale. 
In this first subscale, it was noticed that in $85.4 \%$ of the patients, the partner or other family members supported the adoption of a low salt diet. However, this support was not enough for more than half of the participants to fully agree with the statement "I usually want to do what my partner or family members think I should do".

Studies show that family support is pointed out as a determining factor in adhering to treatment ${ }^{(5)}$, as well as health education, which, in addition to reaching patients, must also reach family members. In this matter, it is important to consider the influence that relatives have on HF patients, once they can share or take full responsibility for the preparation of meals and establish medication schedules ${ }^{(13,16)}$.

The subscale attitude and subjective norm also showed that attitudes were more frequently influenced by the relation with health professionals, followed by influence of partner and family members. Another study confirmed the positive results of social relationships between patients and their health professionals and family members in adhering to a hyposodic diet ${ }^{(6)}$.

The main beliefs of patients regarding the dietary restriction of sodium are the benefits for the improvement of the cardiac condition, in the well-being, in the reduction of the edema and improvement in the breathing. Some studies demonstrate greater benefits in reducing the accumulation of fluids in the ease of breathing, in well-being and in the heart condition among the individuals most adherent to the hyposodic diet. In addition, the literature associates positive attitudes towards a low sodium diet with greater perceived control over your health condition ${ }^{(6,17-18)}$.

In the Perceived Behavioral Control subscale, the main barriers identified by behavioral control were insufficient willpower to follow a hyposodic diet, as well as a predilection for salty foods and the taste of low salt foods. These barriers were also mentioned in other research ${ }^{(5-6,12,17)}$. One of these studies also found a significant association between non-adherence and lack of will power to change their diet ${ }^{(17)}$.

It was found relevant satisfactory adherence only in the first subscale, which shows that there is a belief about the positive results of the diet. On the other hand, when it comes to the behavioral aspect in the other components, it is there that the greatest challenge for adhering to the hyposodic diet is found and it is in this space the field of action of health professionals so that in a gradual process, through education in the health of patients and family members, enable behavioral changes ${ }^{(19)}$. In the national literature, it was verified scores similar to those found in this study, also evidencing a satisfactory adherence predominant in the component subjective attitude and norm ${ }^{(6)}$.
Studies carried out in other countries also highlight similar results, as they have identified satisfactory scores in terms of beliefs and subjective norms, in addition to finding scores that indicate low behavioral control ${ }^{(9,12)}$. It is important to note that such comparisons were not due to the numerical values of the scores, since the scale validated for the Brazilian context has undergone some changes in its components and their evaluation scores, not being numerically equivalent.

Regarding the dietary pattern of the interviewees, more than half of the patients deny the habit of eating outside home and the consumption of processed foods, which may be related to unemployment and the low income of most participants. The data reveal that most patients try to follow a low salt diet when preparing food in their own homes.

Higher family income was associated with unsatisfactory adherence to the attitude and subjective norm component, a fact that may reflect greater access to food prepared outside the home and in commercial establishments. However, it must be considered that a healthy diet can be more expensive and, therefore, difficult to access for the low-income population, making this group also vulnerable to unsatisfactory adherence to a hyposodic diet. This situation was found in a study conducted in Singapore, in which low family income was associated with unsatisfactory scores in attitude and subjective norm ${ }^{(12)}$.

Satisfactory adherence to the attitude and subjective norm was also associated with the control of the cardiac condition, demonstrating that positive attitudes and beliefs, with regard to the hyposodic diet, reverberated in better clinical outcomes. Another study agrees with this finding, since it found a lower left ventricular ejection fraction among individuals with decompensated HF hospitalized due to non-adherence to a hyposodic diet, compared to the group with hospitalization for other causes ${ }^{(6)}$.

Family history of chronic renal insufficiency was associated with satisfactory adherence to perceived behavioral control. Similarly, in the dependent behavior component, there was an association between satisfactory adherence and family history of heart failure, as well as family adherence to a dietary sodium restriction. Such findings reinforce that adherence to sodium restriction in food starts in the family context, since most patients need help from other family members to cook, and thus, when there is a family member affected by chronic diseases whose treatment involves dietary moderation of sodium, it is easier to have the involvement of relatives and consequently a possible improvement in adherence to the diet ${ }^{(19)}$. 
Considering the existence of facilitators who assist in adhering to a sodium-restricted diet, such as family support and health education, it is essential that nursing acts in this context. It is also important to highlight, as a strategic space for such action, the family health territories, in which there is a closer bond with the individual and his family, a scenario that enhances self-care, greater adherence to treatment and better quality of life for the patient with heart failure.

The performance of this study found limitations in the assessment of the subscale of dependent behavior, which considers food in restaurants in most of its questions, and the population studied has a predominant low income and does not frequent restaurants to eat. Such fragility denotes the need for other studies to adapt the subscale of behavior dependent on the DSRQ for individuals who do not frequent restaurants.

\section{Q CONCLUSIONS}

With regard to adherence to sodium control in the diet, the attitudes and beliefs that contribute to it are related to the social relationships of individuals with their relatives and health professionals, and with the belief that the diet will improve the health condition. In the barriers that affect adherence to dietary sodium restriction is the taste of unsalted foods and lack of willpower dietary change.

There was statistically significant relation between income and heart condition control with satisfactory adherence to attitude and subjective norm; family history of CRI and satisfactory adherence with perceived behavioral control, and family history of HF and salt-restricted relatives with satisfactory adherence to Dependent Behavior.

Based on these results, which reveal some groups and situations of risk for a low adherence to hyposodic diet, it is possible an acting for the multidisciplinary team in strengthening appropriate dietary habits for this population.

\section{REFERENCES}

1. Albuquerque $D C$, et al. Diretriz Brasileira de Insuficiência Cardíaca Crônica e Aguda. Arq Bras Cardiol. 2018 [cited 2019 Aug 20];111(3):436-539. Available from: https://www.scielo.br/pdf/abc/v111n3/0066-782X-abc-111 -03-0436.pdf

2. Rodrigues MM, Alvarez AM, Rauch KC. Trends in hospitalization and mortality for ambulatory care sensitive conditions among older adults. Rev Bras Epidemiol. 2019; 22:e190010. doi: https://doi.org/10.1590/1980-549720190010

3. Ministério da Saúde (BR). Datasus. Morbidade hospitalar do SUS (SIH/SUS). Brasilia; c2020 [cited 2020 Jan 06]. Available from: http://datasus.saude.gov. br/acesso-a-informacao/morbidade-hospitalar-do-sus-sih-sus
4. Soares FLJ, Oliveira JMG, Freire GNC, Andrade LC, Noya-Rabelo MM, Correia LCL. Incremental prognostic value of conventional echocardiography in patients with acutely decompensated heart failure. Arq Bras Cardiol. 2017 [cited 2019 Aug 10];109(6):560-8. doi: https://www.scielo.br/pdf/abc/v109n6/0066-782Xabc-20170173.pdf

5. Rabelo-Silva ER, Saffi MAL, Aliti GB, Feijó MK, Linch GFC, Sauer JM, et al. Precipitating factors of decompensation of heart failure related to treatment adherence: multicenter study-EMBRACE. Rev Gaúcha Enferm. 2018;39:e20170292. doi: https://doi.org/10.1590/1983-1447.2018.20170292

6. Barilli SLS, d'Almeida KSM, Trojahn MM, Souza GC, Aliti GB, Rabelo-Silva ERR. Knowledge, barriers and attitudes toward dietary sodium in patients with decompensated heart failure. J Nurs Educ Pract. 2018;8(1):98-106. doi: https:// doi.org/10.5430/jnep.v8n1p98

7. World Health Organization (CH). Hearts: technical package for cardiovascular disease management in primary health care. Geneva: WHO; 2016 [cited 2019 Aug 23]. Available from: http://apps.who.int/iris/bitstream/10665/ 252661/1/9789241511377-eng.pdf?ua=1

8. Girão ALA, Freitas CHA. Hypertensive patients in primary health care: access, con-nection and care involved in spontaneous demands. Rev Gaúcha Enferm. 2016 jun;37(2):e60015. doi: https://doi.org/10.1590/ 1983-1447.2016.02.60015

9. Wu JR, Lennie TA, Dunbar SB, Pressler SJ, Moser DK. Does the theory of planned behavior predict dietary sodium intake in patients with heart failure? West J Nurs Res. 2017 Apr;39(4):568-81. doi: https://doi. org/10.1177/0193945916672661

10. D’Almeida KSM, Souza GC, Rabelo ER. Cross-cultural adaptation into Brazilian Portuguese of the Dietary Sodium Restriction Questionnaire (DSRQ). Arq Bras Cardiol. 2012;98(1):70-5. doi: https://doi.org/10.1590/ S0066-782X2011005000122

11. D'Almeida KSM, Souza GC, Rabelo-Silva ER. Validity and reliability of the Dietary Sodium Restriction Questionnaire (DSRQ). Nutr Hosp. 2013 Sep-Oct; 5(28):1702-9. doi: https://doi.org/10.3305/nh.2013.28.5.6679

12. Ling RZQ, Jiao N, Hassan NB, He H, Wang W. Adherence to diet and medication and the associated factors among patient with chronic heart failure in a multiethnic society. Heart Lung. 2020;49(2):144-150. doi: https://doi.org/10.1016/j. hrtlng.2019.11.003

13. Lessa QCSS, Frossard JM, Santos FAS, Queluci GC, Correia DMS, Cavalcanti ACD. Nursing actions for patients with heart failure: an integrative review. Rev Pesqui Cuid Fundam (online). 2016;8(2):4587-600. doi: https://doi.org/ 10.9789/2175-5361.2016.v8i2.4587-4600

14. Carpenito, LJ. Manual de diagnósticos de enfermagem. 15. ed. Porto Alegre: Artmed; 2018

15. D’Almeida KSM, Barilli SLS, Souza GC, Rabelo-Silva ER. Cut-Point for Satisfactory Adherence of the Dietary Sodium Restriction Questionnaire for Patients with Heart Failure. Arq Bras Cardiol. 2019 [cited 2019 Aug 20];112(2):165-70. Available from: https://www.scielo.br/pdf/abc/v112n2/0066-782X-abc-112 -02-0165.pdf

16. Dunbar SB, Clark PC, Reilly CM, Gary RA, Smith A, McCarty F, et al. A trial of family partnership and education interventions in heart failure. J Card Fail. 2013;19(12):829-41. doi: https://doi.org/10.1016/j.cardfail.2013.10.007

17. Misook LC, Linda P, Susan KF, Terry AL. Long-term adherence to low-sodium diet in patients with heart failure. West J Nurs Res. 2017;39(4):553-67. doi: https:// doi.org/10.1177/0193945916681003 
Bezerra SMMS, Lopes BS, Bomfim PP, Belo RMO, Nascimento MO, Araújo HVS, Braga ASA

18. Seongkum H, Terry AL, Susan JP, Sandra BD, Misook LC, Debra KM. Factors associated with perceived control and the relationship to quality of life in patients with heart failure. Eur J Cardiovasc Nurs. 2015;14(2):137-44. doi: https://doi.org/10.1177/1474515113519931
19. Akhondzadeh K, Ghezeljeh TN, Haghani H. The effect of the education program on the adherence intention to the dietary sodium restriction and the amount of sodium intake in patients with chronic heart failure. Iran Red Crescent Med J. 2018 Dec;20(S1):e12925. doi: https://doi.org/10.5812/ircmj.12925

\section{- Corresponding author:}

Monique Oliveira do Nascimento

E-mail: moniquenascimento16@gmail.com

\section{Associate editor:}

Editor-in-chief:
Maria da Graça Oliveira Crossetti 